\title{
Assessing ESP in 'Math Technique' Branches \\ The Case of Civil Engineering BAC English Tests from 2010 to 2015
}

\begin{abstract}
:
In ESP testing, we are concerned with making inferences about the extent to which test takers can use language in contexts similar to their fields of study. In order to justify the score interpretations, and the purposes for which theyare intended to be used, two types of authenticity need to be provided. First, the pupils' instructional syllabus needs to correspond to language situations in specific target domains.Second, tests should sample their content and tasks from ESP relevant contexts. In this article, we attempt to conduct an empirical analysis to examine the extent to which these criteria are implementedin civil engineering specialties at the secondary school.
\end{abstract}

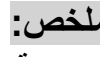

$$
\begin{aligned}
& \text { تهدف اختبار ات اللغة الانجليزية ذات الأغراض الخاصة } \\
& \text { إلى قياس مدى كفاءة المتعلمين على استعمال هذه اللغة في تلات } \\
& \text { سياقات ممائلة لميادين تخصصاتهم الدراسية. ولكي نتمكن من } \\
& \text { الحصول على نتائج معبرة عن المستوى الحقيقي لهؤلاء } \\
& \text { المتعلمين, يوصي المتخصصون بأن تكون وحدات البرنامج }
\end{aligned}
$$

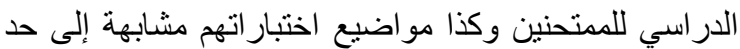

$$
\begin{aligned}
& \text { كبير لميادين تخصصاتهم المدرسية. نقوم في البحث بإجر اء } \\
& \text { دراسة تحليلية لقياس مدى تطابق اختبارات اللغة الانجليزية }
\end{aligned}
$$

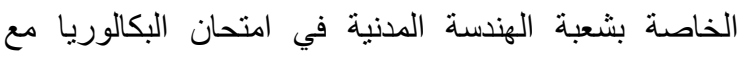

$$
\begin{aligned}
& \text { المعايير التي يوصي بها المتخصصون في مجالات القياس لفئس } \\
& \text { و التقيبيم. }
\end{aligned}
$$

\section{Mohammed NAOUA}

Faculté des Lettres et des Langues. Département d'Anglais Université Chahid Hamma Lakhdhar Eloued

\section{Introduction: \\ Testing Language ability} refers to the process of making inferences about learners' language competence and about the extent to which they can use this competence in real target domains beyond the test itself. This process is built upon two main components: the 'what' and the 'how'. 
The former refers to the constructs that we intend to measure and the latter pertains to the methods through which we can assess these constructs. The 'what' of testing requires the description of the models of language ability from which tests are to be developed. In the same way, this component delimits the constructs and specifies them for particular testing situations. On its part, the test method delineates the characteristics of test tasks and ensures their authenticity to real language use tasks (Bachman, 1990).

In engineering streams, for instance, language testers emphasize that testing needs to be adapted to respond to the specific requirements of each field of specialization. This implies that the specific language ability to be tested comes as result of the interaction between learners' language competence and their specific background knowledge by means of their strategic competence involved by the extent of the specificity of the test content. In other words, the more the test content is field-specific, the more test takers' language ability is engaged by its input.

\section{Describing Language Ability}

Language testers underline that any test has a model of language ability behind it (Alderson, 2000; Alderson, Clapham \& Wall, 1995; Bachman, 1990, 1991; Bachman \& Palmer, 1996, Purpura, 2004). This model describes how language functions, how its components interact, and how the target language use can be defined. Additionally, it accounts for the way people use language in real contextual situations. As far as testing is concerned, these testers believe that "the design of every language test, no matter how narrow its focus, [it] should be informed by a broad view of language ability" (Bachman \& Palmer, 1996, p. 67). For this reason and before talking about tests in civil engineering specialties, we need to provide a detailed description of communicativecompetence in ESP contexts.

\subsection{Describing Language Ability in LSP contexts}

Deriving from Hymes (1972), Savignon (1972, 1991, 2002), Canale and Swain (1980),Hutchinson and Waters (1987),Dudley-Evans and St. John (1998), Bachman (1990, 1991), and Bachman and Palmer (1996), Douglas (2000) outlines a model of specific purpose language ability comprising three components: language knowledge, background knowledge and strategic competence (see Fig 1). In this model, language and background knowledge interact internally by means of strategic competence, and externally with the specific purpose input in the case of language testing; and with the specific target language domain in the case of real language use. Specific language ability is likely to be engaged when the test taker feels that the test content is highly specific and related to his field of specialization (Bachman, 1990, Bachman \& Palmer, 1996; Douglas, 2000, 2001, 2005, 2010a, 2010b, 2013). 
Fig 1: Specific Purpose Language Ability

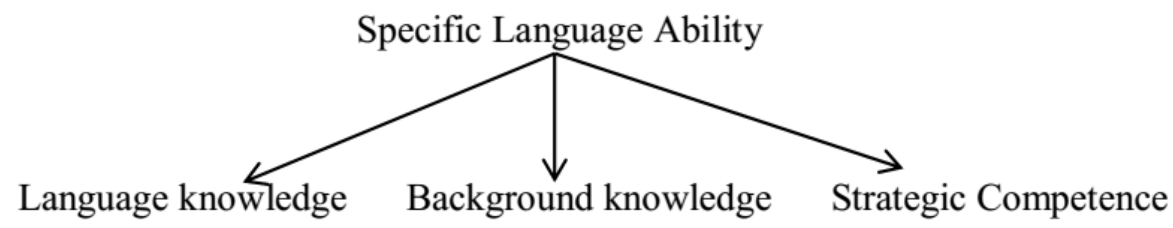

Organized from Douglas, 2000, p. 35

\subsubsection{Language Knowledge}

Language knowledge can be defined as the "domain of information that is specific to language ability and that is stored in long-term memory" (Bachman, 1991, p. 686). Building largely upon Bachman (1990, 1991), and Bachman and Palmer(1996), Douglass (2000) thinks of language knowledge to be including two large competencies (see Fig 2): organizational knowledge and pragmatic knowledge. The former is subdivided into grammatical and textual knowledge, and the latter is rearranged into functional and sociolinguistic knowledge. Grammatical knowledge encompasses vocabulary, morphology, syntax, and phonology. Textualknowledgecomprises the knowledge of cohesion and rhetorical or conversational organization. Pragmatic knowledge describes learners' functional and sociolinguistic knowledge. The former includes ideational, manipulative, heuristic, and imaginative functions; while the latter specifies the knowledge of dialects and varieties, registers, idiomatic expressions and cultural references.

Fig 2: Components of Language Knowledge

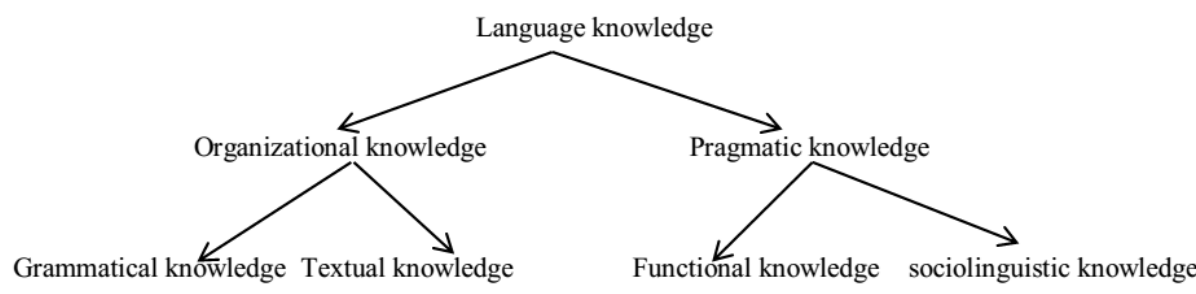

Organized from Douglas, 2000, p. 35

\subsubsection{Background Knowledge}

In ESP contexts, background knowledge (BK) can be thought of test takers' prior knowledge of the subject matter included in the test input 
(Bachman, 1990, 1991; Basturkmen, 2006, 2010, Basturkmen \& Elder, 2004; Douglas, 2000, 2001, 2005, 2010b).Douglas ( 2010a) defines this type of knowledge as the "frames of reference based on past experience which we use to make sense of current input and make predictions about that which is to come" (p.31). In measuring general communicative language ability, (BK) is considered as one type of the construct irrelevant variances. This is becausebecause "when the specific test material, either deliberately or inadvertently, is highly familiar to some respondents[it]leads to scores that are invalidly high for the affected individuals as reflections of the construct under scrutiny" (Messick, 1995, p. 273). Conversely, in ESP contexts where learners are supposed to form homogeneous groups, testing specialized knowledge forms a part of the construct to be measured (Alderson \& Urquhart 1985; Bachman, 1990).

\subsubsection{Strategic Competence}

Several definitions have been proposed to strategic competence (SC) in the literature of language testing. According to Canale and Swain (1980), this component is usually "called into action to compensate for breakdowns in communication due to performance variables or to insufficient competence" (p. $30)$ on the part of test takers. Bachman $(1990,1991)$ and Bachman, and Palmer (1996) consider strategic competence as the metacognitive processes, which enable test takers to integrate the different sectors of their language competence, their previous real-world knowledge, and their affective schemata to be engaged by the test input.

\subsubsection{Strategic Competence in ESP Test Taking}

Building upon Canale and Swain (1980), Tarone (1981),Farch and Kasper (1983, 1984),Bachman and Palmer (1996),Dörnyei (1995), and Dörnyei and Scott (1997), Douglas(2000)identifies tworoles for strategic competence. First, itenablestest takers' different sectors of language competence to interact with their background knowledge.At the same time, it canserveasamediator between the previous traits and the external specific context. Douglas organizes (SC) into two sets of processes: metacognitive strategies (MSs) and communication strategies (CSs). The relationship between these two sets is hierarchical in that it is the (MSs)that "direct the interaction of language users with the context while communication strategies are called on by their metacognitive strategies to take over direction when the features of the context are specifically identified as communicative" (pp. 76-77). In other words, when test takers feel that test performance on the test does not require the use of language, their (MSs) are engaged to take action.However when the situation requires communicative proficiency, their(MSs) direct their CSs to take action. 


\subsubsection{Phases of Strategic Competence}

In ESP testing, strategic competenceis made up of four phases: assessment, goal setting, planning, and control of execution. In the first phase, the test taker analyzes the characteristics of the specific situation and attempts to engage an appropriate discourse domain. In stage two, hedeterminesthe goals that he intends to achieve by engaging that type of discourse. In the planning stage, the test taker selects the aspects of language and background knowledge relevant to the testing context. In the fourth phase, he executes his plan by engaging production or comprehension by means of appropriate psychophysiological mechanisms (Bachman, 1990).

\section{Specific Language Tests}

An LSP test can be defined as the:

one in which content and method are derived from an analysis of specific purpose target language use situation, so that test tasks and content are authentically representative of tasks in the target situation, allowing for an interaction between the test takers' language ability and specific purpose content knowledge, on the one hand, and the test tasks on the other. Such a test allows us to make inferences about test takers' capacity to use language in the specific purpose domain. (Douglas, 2000, p. 41)

As the definition above implies, language testers constrain LSP tests to the ones, which result from an analysis of test takers' specific target needs. The latter refer to "learners' goals and backgrounds, their language proficiencies, their reasons for taking the course, their teaching and learning preferences, and the situations they will need to communicate in" (Hyland, 2006, 73-74). The correspondence between the test content and the examinees' needs allows for a positive interaction between their language ability and the test tasks, enabling us to make valid and reliable inferences about their specific language competencies.

\subsection{Characteristics of LSP Tests}

Language testers identify three characteristics of LSP tests: authenticity of task, specificity of content and interaction between language knowledge and the specific purpose content knowledge (Bachman, 1990; Douglas, 2000, 2001, 2005, 2013). The first characteristic requires test tasks to "share critical features of tasks in the target specific purpose language use situation of interest to test takers" (Douglas, 2001, p, 46). Bachman (1991) identifies two types of authenticity: situational and interactional.Hedefines the former as"the perceived 
relevance of the test method characteristics to the features of a specific target language use situation"(p. 690).The authorexplains that "if test takers were specialists in engineering,it is likely that inclusion of technical terms and topics from engineering would tend to increase the situational authenticityof the test" (p. 690). Concerning interactional authenticity, it is "a function of the extent and type of involvement of task takers' language ability in accomplishing a test task" (p. 690). This type is much more related to the second characteristic 'specificity of content' which refers to the extent to which the test content can engage test takers' specific language ability to interact with the test input (Douglas, 2000, 2001, 2005). The third characteristic is related to test takers'backgroundknowledge, which is considered as a constituent of the construct to be measured. Bachman (1990) reminds us that"if we develop a language for specific purpose reading test under the assumption of specific language abilities, we are, in effect, defining specialized knowledge aspart of the language ability to be tested" (274).

\section{Specific Target Language Domains}

Target language use domains refer to "a set of specific language use tasks that the test taker is likely to encounter outside the test itself, and to which we want our inferences about language ability to generalize" (Bachman \& Palmer, 1996). Applied linguists classify these tasks into two types: real-life domains and instructional domains. The first type describes the contexts where language is used for communicative purposes. The second type accounts for the situations in which language is used for instructional purposes (teaching and learning). In order for test takers' language competence to be engaged by the test input, applied linguists and language testers emphasize that the instructional domain and test tasks should be considered as a special instance of real target domains. Similarly, learners and examinees need to be considered as a sample of the large population of thespecific real-life language users (Basturkmen \& Elder, 2004).

\subsection{Learning Needs in Civil Engineering Specialties}

Learning needs refer to "learners' goals and backgrounds, their language proficiencies, their reasons for taking the course, their teaching and learning preferences, and the situations they will need to communicate in. Needs can involve what learners know, don't know, or want to know" (Hyland, 2006, 73-74). Applied linguists classify learners' needs into three sets:targetsituation needs, or necessities, learners' present deficiencies or lacks and wants (Hutchinson \& Waters, 1987; West, 1997). Necessities include "the type of need determined by the demands of the target situation, that is, what the learner has to know in order to function effectively in the target situation" (Hutchinson $\&$ Waters, 1987, p. 55). Identifying present deficiencies requires us first to 
determine what learners already know so that we can decide what they lack in terms of language knowledge to enable them to communicate in the specific target situations.

Target needs in civil engineeringinclude language situations relatedto "the design of static structures such as buildings, roads, tunnels, and bridges and the control of water and its contaminants" (Harris, 2006, p. 213); and to the field of architects which describes "the art and science of designing and building structures, communities, or open areas, in keeping with aesthetic and functional criteria" (p.50). In his book 'English for Architects and Civil Engineers', Heidenreich (2008) identifies several situations where English can be used by civil engineering specialties. These include project basics, preliminary enquiries, briefing, preliminary design, final design, planning and building permission, tender documentation, tender action, pre-construction phase, construction phase, and completion.

\section{Methodology}

This paper attempts to conduct an empirical analysis of civil engineering pupils' BACEnglish tests from 2010 to 2015 in order to measure the extent of their authenticity to the specific target domains to which test scores are supposed to be generalized. Seeing that this investigation is not concerned with electing information from any type of population, we limited the data gathering tools to documentary sources.

\subsection{Describingthe Relevant Data Gathering Tools}

Research methodologists classify documentarysources according to their authorship and access (Jupp, 2006; Scott, 1990). The first category refers to the origin of documents. The second one describes the extent ofavailability of these documentsto researchers. Authorship is also subdivided into official and personal documents. The former which can be found in bureaucracies are organized into state (governmental) and private (non-governmental) documents. Concerning the second standard,research methodologists identify four types of access: closed, restricted, open-archival and open-published.The documentary sources relevant to this research include official open-published data in the form of ten English tests relevant to the BAC sessions from 2010 to 2015(ONEC, 2010-2015) as well the instructional syllabus of civil engineering specialties (Ministry of Education, 2014-2015a;Ministry of Education, 2014$2015 b)$. This type of document is "the most accessible of all and [is] in general circulation" (Jupp, 2006, p.277).

\section{Data Analysis}

5.1 Analysis of the Instructional Domain in Civil Engineering Specialties 
The Ministry of Education (2014-2015a, 2014-2015b) emphasizes that the main objective of teaching English in the third year classes is to engage "learners in real and meaningful communication. By real we mean that the learners are given opportunities to process content relating to their lives and backgrounds" (p. 9).In this perspective, the Ministry adds that the third year book 'New Prospects' "caters to the needs of the major Baccalauréatstreams" (Ministry of Education (2014-2015b, p.11) and that the syllabus designers and book writers "have tried to strike a balance between topics related to science and technology and others related to language and humanities" (p. 11).

The third year syllabus in secondary education is built around six thematic units which include, as Table 1 implies: (1) ancient civilization, (2) ethics in business, (3) education in the world, (4) advertising, consumers and safety, (5) astronomy and the solar system and (6) feelings and emotions (Ministry of Education, 2014-215a). Units 2, 4, 5 and 6 are intended to the following branches: economics and management, Natural and exact sciences as well as 'math techniques' (technology) streams. The latter are organized into four specialties: civil engineering, electrical engineering, mechanical engineeringand engineering of processes(Ministry of Education, 2014-2015a; 2014-2015b).

Table 1: Themes in Civil Engineering Pupils' Instructional Domain

\begin{tabular}{|c|l|l|l|}
\hline Unit & \multicolumn{1}{|c|}{ Unit Titles } & \multicolumn{1}{|c|}{ Themes } & \multicolumn{1}{c|}{ Project Outcome } \\
\hline 01 & Exploring the Past & Ancient Civilizations & $\begin{array}{l}\text { Making the profile of an } \\
\text { Ancient Civilization }\end{array}$ \\
\hline 02 & $\begin{array}{l}\text { Ill-Gotten Gains Never } \\
\text { Prosper }\end{array}$ & $\begin{array}{l}\text { Ethics in Business: Fighting Fraud } \\
\text { and Corruption }\end{array}$ & Writing a Charter of Ethics \\
\hline $\mathbf{0 3}$ & $\begin{array}{l}\text { Schools: Different and } \\
\text { Alike }\end{array}$ & $\begin{array}{l}\text { Education in the World: } \\
\text { Comparing Educational Systems }\end{array}$ & $\begin{array}{l}\text { Designing an Educational } \\
\text { Prospectus }\end{array}$ \\
\hline 04 & Safety First & $\begin{array}{l}\text { Advertising: Consumers and } \\
\text { Safety }\end{array}$ & $\begin{array}{l}\text { Conducting a Survey on the } \\
\text { Impact of Advertising }\end{array}$ \\
\hline $\mathbf{0 5}$ & $\begin{array}{l}\text { It' a Giant Leap for } \\
\text { Mankind }\end{array}$ & Astronomy and the Solar System & $\begin{array}{l}\text { Designing an Astronomy } \\
\text { Booklet }\end{array}$ \\
\hline $\mathbf{0 6}$ & We are a Family & $\begin{array}{l}\text { Feelings, Emotions, Humor and } \\
\text { Related Topics }\end{array}$ & $\begin{array}{l}\text { Writing a Booklet of Tips for } \\
\text { Coping with Strong Emotions }\end{array}$ \\
\hline
\end{tabular}


Ministry of Education, 2014-2015b

\subsection{Analysis of Civil Engineering BAC English Tests from 2010 to 2015}

In the same way, we used the data which we have collected by means of civil engineering BAC English tests from 2010 to 2015 to measure the extent of their authenticity with the pupils' academic or future occupational domains. As Table 2,implies the theme 'Astronomy' was included in topic 2 of the following sessions: 2011, 2013; and in topic 1 in 2015. What is worth mentioning here is that the same theme has formed part of the written expression section of test 1 in 2014; and of test 2 in 2015.Themes from unit four 'Advertising: Consumers and Safety' formed part of the following sessions: topics 1 and 2 in 2010; topic 1 in 2011, 2013, 2014; and topic 2 in 2015. Ethics in business was included in topic 1 in 2012 and in topic 2 in 2015.

Table 2: BAC English Test topics from 2010 to 2015

\begin{tabular}{|c|l|l|l|}
\hline Session & \multicolumn{1}{|c|}{ Test Themes } & \multicolumn{2}{|c|}{ Written Expression Topics } \\
\hline \multirow{2}{*}{2010} & Child Labor & Child Labor & Hazardous Child Labor \\
\cline { 2 - 4 } & Advertising & Travel Agency Services & Advertising \\
\hline \multirow{2}{*}{2011} & Advertising & Product Competitiveness & Counterfeited Products \\
\cline { 2 - 4 } & Astronomy: Water on the Moon? & Life on the Moon & Importance of Water \\
\hline \multirow{2}{*}{2012} & Business: Companies Performance & Companies Performance & Food Safety \\
\cline { 2 - 4 } & Astronomy: Quasars & Describing Planet Mercury & Obesity and Fast Foods \\
\hline \multirow{2}{*}{2013} & Child Labor & Life on Mars and on the Earth & Effects of Intoxicated Fast Foods \\
\cline { 2 - 4 } & Hubble Space Telescope & Child Labor & Advertising \\
\hline \multirow{2}{*}{2014} & Consumer Habits & Consumers' associations & Space Tourism \\
\cline { 2 - 4 } & Counterfeited Paper Currencies & Fighting Counterfeiting & $\begin{array}{l}\text { The Effects of Fast Foods } \\
\text { Advertising on Kids' s Health }\end{array}$ \\
\hline \multirow{2}{*}{2015} & Life on the Moon & Space Research & Salesmen and Price Regulations \\
\cline { 2 - 4 } & Eating Habits in America & Causes of Obesity & Space Exploration \\
\hline
\end{tabular}

ONEC, 2010-2015

\section{Results}

As table (1) implies, themes in units 2 and 4 are tightly related and both account for topics in connection to business and economics. Seeing that the syllabus is built around four units, we can conclude that $50 \%$ of the program of study falls in the preferences of one specialty, 'economics and management'. Conversely, as far as civil engineering pupils are concerned none of the syllabus constituents has coincided with the requirements of their sphere of specialization. According to the specialists in the field, the discrepancy between the pupils' syllabus and their target needscan slow down the process of 
language learning; which will eventually affect their achievement on the test (Bachman, 1990; Douglas, 2000, 2001; Hutchinson \& Waters, 1987).

The second point relevant to this analysis concerns the authenticity between the constructs being measured and the pupils' needs or specific target domains. As we have mentioned previously, topics in unit 2 'Ethics in Business' and the ones in unit 4 'Advertising: Consumers and Safety' emerge from the same thematic context. Consequently, if we count the tests included in Table (3), we conclude that out of the 12 tests, whichhave been administered from 2010 to 2015, eight ones are in tight connection with economics and management's target and instructional needs. This means that from 2010 to 2015, civil engineering's needs have completely been discounted. Language testers stress that when measures are not highly field-specific, they can hardly allow test takers' language and background knowledge to be engagedby the input. This implies that the process of language testing in civil engineering did not provide comparable opportunities to the third year learners to demonstrate their standing on the constructs, which the Ministry of Education has planned to assess.

Table 3: The BAC English Tests responding to Economics and Management Needs

\begin{tabular}{|c|c|l|l|}
\hline Session & Test & \multicolumn{1}{c|}{ Theme } & \multicolumn{1}{c|}{ Topic } \\
\hline 2010 & 1 & Advertising: consumers and safety & Child Labor \\
\hline 2010 & 2 & Advertising: consumers and safety & Advertising \\
\hline 2011 & 1 & Advertising: consumers and safety & Advertising \\
\hline 2012 & 1 & Ethics in Business & Business companies performance \\
\hline 2013 & 1 & Advertising: consumers and safety & Child labor \\
\hline 2014 & 1 & Advertising: consumers and safety & Consuming habits \\
\hline 2014 & 2 & Ethics in Business & Counterfeited paper currencies \\
\hline 2015 & 2 & Advertising: consumers and safety & Eating habits in the USA \\
\hline
\end{tabular}

Organized from ONEC, 2010-2015 


\section{Conclusion}

Testing language in civil engineering specialties refers to the process of making inferences about the pupils' specific communicative ability; and about the extent to which they can use this ability in the domains to which test scores are supposed to be generalized. In order to engage the pupils' language knowledge to interact with the test input, three types of authenticity need to be provided. First, the pupils' instructional syllabus needs to be similar to language use in real contexts. Second, test tasks should correspond to tasks in target domains. Third, the characteristics of test takers should be delineated on the basis of target real-life participants' characteristics. To measure the extent to which these criteria have been implemented, we conducted an empirical analysis of the data that we have gathered by means of the BAC English tests covering the sessions from 2010 to 2015 . The results of the analysis revealed that none of the syllabus units,northe BAC tests have responded to the interests of civil engineering's streams. This means that both syllabus designers and test developers have failed to comply with the commitments of the Ministry of Education (2014-15a, 2014-2015b) which imply that instructional domains and exams should respond to the pupils' fields of specialization and background knowledge.

\section{Reference List}

Alderson, J. C. (2000a). Assessing Reading. Cambridge: Cambridge University Press.

Alderson, J. C.\& Urquhart, A. (1985). The effect of students' academic discipline on their performance on ESP reading tests.Language Testing, 2, 192-204. From http://ltj.sagepub.com/cgi/content/abstract/2/2/192

Alderson, J. C., Clapham, C., \& Wall, D. (1995).Language testing construction and evaluation. Cambridge: Cambridge University Press.

Bachman, L. F. (1990). Fundamental Considerations in Language Testing. Oxford: Oxford University Press.

Bachman, L. F. (1991). What does Language Testing Have to Offer? TESOL Quarterly, $25 \quad$ (4), 671-704. http://www.jstor.org.www.sndl1.arn.dz/stable/pdfplus/3587082.pdf

Bachman, L. F., \& Palmer, A. S. (1996).Language testing in practice.Oxford: Oxford University Press.

Basturkmen, H. (2010). Developing courses in English for specific purposes . Basingstoke, UK : Palgrave/Macmillan.

Basturkmen, H. (2006). Ideas and Options in English for Specific Purposes. Mahwah, NJ: L. Erlbaum Associates.

Basturkmen, H., \& Elder, C. (2004). The practice of LSP. In A. Davies \& C. Elder (Eds.), The handbook of applied linguistics (pp. 672-694). Oxford: Blackwell 
Canale, M., \& Swain, M. (1980). Theoretical bases of communicative approaches to second language teaching and testing. Applied Linguistics, $1(1), 1-47$.

Dörnyei, Z. (1995). On the Teachability of Communication Strategies.TESOL quarterly 29( 1), 55 85. From http://www.jstor.org/stable/3587805

Dörnyei, Z., \& Scott, L, M. (1997).Communication strategies in a second language:Definitions and taxonomies. Language Learning, 47 (1), 173210. From

Douglas, D. (2000). Assessing Languages for Specific Purposes. Cambridge: Cambridge University Press.

Douglas, D. (2001). Three problems in testing language for specific purposes: Authenticity, specificity and inseparability. In C Elder et al (eds). Experimenting with uncertainty: Essays in honour of Alan Davies (pp. 45-51). Cambridge: Cambridge University Press.

Douglas, D. (2005). Testing Language for Specific Purposes.(2005).In H. Hinkel (ed.), Handbook of research in second language teaching and learning. (pp.857-868). Mahwah, NJ: London,, UK: Lawrence Erlbaum Associates Publishers.

Douglas, D.(2010a). Understanding Language Testing.London: Hodder Education.

Douglas, D.(2010b).This won't hurt a bit: Assessing English for nursing.Taiwan International ESP Journal,2(2), 1-16

Douglas, D.(2013). ESP and assessment. In B, Paltridge ., \&Starfield, S. Eds.The handbook of English for specific purposes, (pp. 367-383). England, Chichester: John Wiley \& Sons, Inc

Dudley-Evans, T., \& St. John, M. (1998).Developments in English for Specific Purposes. Cambridge: Cambridge University Press.

Fulcher, G., \& Davidson, F. (eds) (2012). The Routledge Handbook of Language Testing (pp. 455- 468). Abingdon, Oxon: Routledge.

Fulcher, G. (2010). Practical language testing.London, UK: Hodder Education.

Harris, M, C.(2006).The dictionary of architecture and construction $\left(4^{\text {th }} \mathrm{ed}\right)$. New York: McGraw-Hill Companies, Inc,

Heidenreich, S. (2008).English for Architects and Civil Engineers.Auflage: Der Vieweg+TeubnerVerlag

Hyland, K. (2006) English for academic purposes: An advanced resource book (London: Routledge).

Hymes, D. (1972). On communicative competence. In J. Pride \& J. Holmes (Eds.), Sociolinguistics (pp. 269-293). Harmandsworth, UK: Penguin.

Jupp, V. (2006).Documents and Critical Research. In J Sapsford.,\& V, Jupp (Eds). Data collection and analysis ( $2^{\text {nd }}$ ed, pp.272-290). London: SAGE Publications; The Open university. 
Messick, S. (1995).Validity of psychological assessment: Validation of inferences from persons' responses and performances as scientific inquiry into score meaning.American Psychologist, 50 (9)741-749

Ministry of Education.(2014-2015a). New Prospects: Pupils' Course book. Alger: OPS

Ministry of Education.(2014-2015b). New Prospects: Teachers' book. Alger: OPS

Purpura, J. A.(2004). Assessing grammar. Cambridge: Cambridge University

Press.

Savignon, S. J. (1972). Communicative competence: An experiment in foreign languageteaching.Philadelphia, PA: Center for Curriculum Development.

Savignon, S, J. (1991). Communicative Language Teaching: State of the Art.TESOLQuarterly, 25(2), 261-277. http://www.jstor.org.www.sndl1.arn.dz/stable/pdfplus/10.2307/3587463. pdf

Tarone, E. (1981). Some Thoughts on the Notion of Communication $\begin{array}{llll}\text { Strategy.TESOLQuarterly, } 15 & \text { (3), 285-295. } & \text { From }\end{array}$ http://www.jstor.org/stable/3586754 . 